\title{
Morphology, morphometry, and membrane integrity of epididymal spermatozoa of spotted pacas (Cuniculus paca, Linnaeus 1766)
}

\author{
Morfologia, morfometria e integridade da membrana de \\ espermatozoides epididimários de paca \\ (Cuniculus paca, Linnaeus 1766)
}

\author{
Patrícia Andrade dos Santos ${ }^{1}$; Vânia Maria França Ribeiro²; Augusto Luiz \\ Faino Alves ${ }^{3}$; Vanessa Lima da Silva ${ }^{4 *}$; Breno Kalyl Freitas Nascimento ${ }^{5}$; \\ Rafael Augusto Satrapa ${ }^{2}$; Fernando Andrade Souza ${ }^{2}$
}

\section{Highlights:}

Majority (73\%) of the epididymal spermatozoa of Cuniculus paca were normal.

Proximal cytoplasmic droplet was the second most frequent defect found.

Both ACP $-123^{\circledR}$ and Botusemen Special ${ }^{\circledR}$ were efficient extenders.

Intra-acrosomal vesicles were observed in the sperm head.

\begin{abstract}
The objective of this study was to evaluate the morphology, morphometry, and membrane integrity of epididymal spermatozoa of spotted pacas using spermatic cells collected from the epididymal tails of five animals. The flotation method using the ACP $-123^{\circledR}$ and Botusemen Special ${ }^{\circledR}$ extenders was performed, and samples were stained in Diff-Quick and eosin-nigrosine. Descriptive statistics of data were obtained and Student's $t$-test was performed. The morphology of 200 Diff-Quick-stained spermatozoa showed that they had an oval head with three vesicles in the acrosomal region, a midpiece, an elongated tail; moreover, $27 \%$ of the spermatozoa exhibited cellular defects. The morphometry of 100 sperm cells (analyzed with an optical microscope and the EZ Leica LAS software for Windows) presented the following measurements (mean $\pm \mathrm{SD}$ ): total length $43.87 \pm 4.91 \mu \mathrm{m}$, head $7.54 \pm 0.82 \mu \mathrm{m}$, midpiece $5.35 \pm 0.83 \mu \mathrm{m}$, tail $30.72 \pm 2.55 \mu \mathrm{m}$, and head width $5.30 \pm 0.68 \mu \mathrm{m}$. Of the 2,000 cells stained with eosin-nigrosine for membrane integrity evaluation, $83.8 \%$ diluted in ACP- $123^{\circledR}$ and $72.9 \%$ diluted in Botusemen ${ }^{\circledR}$ had intact membranes. The results of this study suggest that epididymal spermatozoa of pacas can be used in assisted reproduction programs; moreover, our study adds knowledge to the reproductive biology of wild animals, and encourages further research on the role of the three acrosomal vesicles present in this species.
\end{abstract}

Key words: Spermatic viability. Epididymis. Morphometry. Semen. Wild animals.

\footnotetext{
1 Médica Veterinária, Rio Branco, AC, Brasil. E-mail: patriciatlesantos@gmail.com

2 Profs. Drs., Medicina Veterinária, UFAC, AC, Brasil. E-mail: vania.rib@uol.com; brsatrapa@yahoo.com.br; femedvet@yahoo. com.br

3 M.e. em Ciência Animal, Universidade Federal do Acre, UFAC, Rio Branco, AC, Brasil. E-mail: gutofaino1@hotmail.com

4 Discente em Medicina Veterinária, UFAC, Rio Branco, AC, Brasil. E-mail: medv.lima18@gmail.com

5 Discente Pós-Graduação em Medicina Veterinária, UFAC, Rio Branco, AC, Brasil. E-mail: breno_kalyl@hotmail.com

* Author for correspondence
} 


\section{Resumo}

Com o objetivo de avaliar a morfologia, a morfometria e a integridade de membrana dos espermatozoides epididimários de paca, células espermáticas oriundas da cauda do epidídimo foram obtidas de cinco animais pelo método de flutuação, utilizando os diluidores ACP- $123^{\circledR}$ e Botusemen Special $^{\circledR}$, coradas em Panótico rápido e Eosina-Nigrosina. Os dados foram analisados por estatística descritiva e teste t de Student. A morfologia de 200 espermatozoides corados em Panótico rápido evidenciou que os mesmos possuíam: cabeça ovalada com três vesículas na região acrossomal, peça intermediária, cauda alongada, sendo os defeitos celulares de 27\%. A morfometria de 100 células espermáticas (efetuada com microscópio óptico e softwares EZ Leica LAS de aquisição de imagens para sistemas operacionais Windows) apresentou as seguintes medidas (média \pm d.p): comprimento total 43,87 $\pm 4,91 \mu \mathrm{m}$, cabeça $7,54 \pm 0,82 \mu \mathrm{m}$, peça intermediária $5,35 \pm 0,83 \mu \mathrm{m}$, cauda $30,72 \pm 2,55 \mu \mathrm{m}$ e largura da cabeça $5,30 \pm$ $0,68 \mu \mathrm{m}$. Das 2.000 células coradas em Eosina-Nigrosina para avaliação da integridade da membrana, $83,8 \%$ das diluídas em ACP $123^{\circledR}$ e 72,9 \% das diluídas em Botusemen ${ }^{\circledR}$ estavam com as membranas intactas. Os resultados sugerem que espermatozoides epididimários de pacas podem ser utilizados em técnicas de reprodução assistida, agregam conhecimentos a esta área e suscitam novos estudos sobre o papel das três vesículas acrossomais características nesta espécie.

Palavras-chave: Animais selvagens. Epidídimo. Sêmen. Viabilidade espermática.

\section{Introduction}

Cuniculus paca (Linnaeus, 1766) represents 8\% of the wild meat consumed by indigenous people, riverside dwellers, and settlers (Emmons, 2016). Captive breeding is indicated to meet market demands for meat, thereby reducing predatory hunting (Ribeiro, Carvalho, Peruquetti, Medeiros, \& Freitas, 2017).

Ribeiro et al. (2017) and Bonilla-Morales, Rodríguez and Murillo (2013) emphasize that pacas have a low reproductive rate, which may be attributed to both males and females. Sánchez (2014) and Correia, Francisco, Souza, Ribeiro, and Gomes (2016) have reported the possibility of captivity breeding of wild animals using breeding biotechnologies used for domestic animals. However, this is a challenge owing to the lack of species-specific knowledge of the reproductive biology of these animals, such as their reproductive anatomophysiology and behavior.

Male reproductive management, as well as knowledge on sperm cell characteristics such as morphology, morphometry, and membrane integrity are essential to increase fertilization rate and implement a breeding selection process, since morphological and morphometric parameters of spermatozoa indicate semen quality, which then predicts an animal's fertilizing capacity (Freneau, 2011; Martins, Dode \& Silva, 2016).

Morphological evaluations can be used to determine the animal's sexual age; moreover, it can determine possible causes for sperm cell defects, such as environmental changes, genetic problems, diseases, or the combination of several factors. Many breeding centers implement mandatory procedures to obtain higher reproductive rates and genetic improvement of the breeding stock (Arruda, Orro, Passos, Costa e Silva, \& Zúccari, 2010). Morphological change is one of the characteristics most related to fertility. A high frequency of morphologically abnormal spermatozoa or the high incidence of a specific defect can reduce fertility (Arruda et al., 2015).

Collecting wild animal semen is a demanding procedure that is not always successful. Assumpção (2017) states that wild animal semen can be collected using ejaculatory (i.e., post-copula collection, electroejaculation, digital manipulation, and stimulation using artificial vagina) and nonejaculatory (i.e., rectal massage of internal organs, use of urethral catheter, and collection from the 
epididymis tail and vas deferens) methods. Castelo (2015) reports that epididymal spermatozoa are considered potential sources of valuable genetic resources for germplasm banks.

The objective of this study was to obtain information on the morphology, morphometry, and membrane integrity of epididymal spermatozoa of Cuniculus paca using two different semen extenders in order to increase the available information on reproductive system biology of wild animals like the spotted paca.

\section{Material and Methods}

This study was authorized by the Animal Ethics Committee and was registered under process number 23107.007421/2017-25, protocol 14/2017 and SISBIO number 41459-1. This study included five male pacas of reproductive age (about 36 months) with a mean weight of $9 \mathrm{~kg}$, selected from the Wild Animal Breeding and Research Program - Caboclinho da Mata (IBAMA register number 509309), located at BR-364, km 30, in the municipality of Senador Guiomard, Acre $\left(10^{\circ} 03^{\prime} 22.2^{\prime \prime} \mathrm{S}, 67^{\circ} 36^{\prime} 03.1^{\prime \prime} \mathrm{W}\right)$.

This study used animals that were slaughtered for consumption following the regulations set by authorities. These males were mechanically contained, stunned, and slaughtered; afterwards, orchiectomy and epididymis dissection were performed using the flotation method described by Yu and Leibo (2002).

Extenders are used to decrease sperm cell concentration per field and to verify membrane integrity. Two types of extenders, one for each epididymis, were used for flotation. Powdered coconut water (ACP-123®) was used for the left epididymis, and Botusemen Special ${ }^{\circledR}$ (milk extender) was used for the right epididymis.

The method described by Sánchez (2014) was used for morphological and morphometric evaluations subjectively conducted by three experienced technicians. Histological slides were prepared with smears of $10 \mu \mathrm{l}$ semen diluted in $\mathrm{ACP} \circledast$ and $10 \mu \mathrm{l}$ diluted in Botusemen Special ${ }^{\circledR}$ and were stained using the Diff-Quick method (Matos, Araújo, Roberto, \& Toniolli, 2008; Arruda et al., 2010).

For morphological evaluation, 200 spermatozoa were analyzed per slide using Olympus phase contrast microscopes at 40x magnification. Defects were classified as major or minor according to the guidelines set by Blom (1973).

For morphometric analysis, 100 spermatozoa were randomly selected from each slide and the following structures were measured: total length $(\mu \mathrm{m})$, head length $(\mu \mathrm{m})$, midpiece $(\mu \mathrm{m})$, tail width $(\mu \mathrm{m})$, and head width $(\mu \mathrm{m})$, and were respectively labeled as A, B, C, D, and E. Images were captured using an Image Acquisition Software for Windows and measured using the EZ Leica LAS EZ software.

The slides were stained with eosin-nigrosine and images were obtained using the software mentioned above. One thousand spermatozoa were analyzed for membrane integrity and sperm viability using each of the extenders. Spermatozoa with intact membrane were colorless and those with membrane lesions stained pink.

The data were analyzed for descriptive statistics (i.e., mean, standard deviation of the mean, and percentage) using Microsoft Excel, and Student's $t$-test was performed to compare spermatozoid membrane integrity with each extender using the Bioestat 5.0 software. $\mathrm{P} \leq 0.05$ was considered a significant value.

\section{Results and Discussion}

Morphological studies of epididymal spermatozoa of Cuniculus paca showed that 73\% of the spermatozoa were normal, while $27 \%$ had defects. Of these, $6.5 \%$ presented minor defects (0.5\% distal cytoplasmic droplet, $5 \%$ rolled tail, and $1 \%$ abaxial implantation), and $20.5 \%$ presented 
major defects ( $10 \%$ isolated head, $9.5 \%$ proximal cytoplasmic droplet, and $1 \%$ tail strongly rolled), with isolated head being the defect most frequently found. This can be associated with problems in spermatogenesis, or with problems in either endocrine or iatrogenic processes (Freneau, 2011); however, slide preparation errors may also have contributed to this anomaly.

Martins et al. (2016) reports that during semen analysis, the ejaculate of healthy domestic animals without reproductive problems should contain more than $70 \%$ normal sperm cells (i.e., without cytoplasmic droplets and with an intact membrane) to facilitate the transport of spermatozoa in the female's reproductive tract. In a similar study on the same species, Ferreira, Guimarães, Luz-Ramos, Bastos and Ohashiom (2004) reported that $48 \%$ of the spermatozoa collected using an artificial vagina presented morphological defects, but these authors did not describe the types of abnormalities found. However, we cannot say that the proportion of abnormal spermatozoa found in this study and in the study by Ferreira, Guimarães, Luz-Ramos, Bastos and Ohashiom (2004) interferes with fertility, since sperm motility patterns were not defined in this species.

Batalha and Oba (2006) analyzed spermatozoa from the epididymis tail of capybaras (Hydrochoerus hydrochaeris), which are rodents in the same order as pacas, using the flotation method, and reported that $28.20 \%$ had major while $24.42 \%$ had minor defects. The author reports that these results can be due to the fact that these spermatozoa came from satellite and submissive males that do not copulate, or due to material contamination with cells from the body of the epididymis, where defect proportion is higher. This type of contamination probably occurred in this study; however, because of the collection technique used, contamination may have occurred to a lesser extent.

Axnér, Ström and Linde-Forsberg (1997) studied the morphology of epididymal spermatozoa in cats before and after ejaculation, and they reported no significant sperm abnormality differences between epididymal spermatozoa collected before and after electroejaculation. The most frequent defect was the occurrence of distal cytoplasmic droplets. According to these authors, these result from the sperm maturation process wherein the sperm passes through the epididymis; moreover, it is the result of the loss of this cytoplasmic remnant during ejaculation.

Table 1 shows that proximal cytoplasmic droplet was the second most frequent defect found. Proximal cytoplasmic droplets interfere with fertility (Fernández-Santos et al., 2007). However, the acceptable maximum limit of this defect in Cuniculus paca spermatozoa before it leads to reproductive interference is not yet known.

Table 1

Mean \pm MSD of morphometric characteristics of Cuniculus paca epididymal spermatozoa obtained by the flotation method

\begin{tabular}{ccc}
\hline STRUCTURE & \multicolumn{2}{c}{ MEASUREMENTS $(\mu M)$} \\
\hline A & Total length & $43.87 \pm 4.91$ \\
B & Head length & $7.54 \pm 0.82$ \\
C & Midpiece & $5.35 \pm 0.83$ \\
D & Tail length & $30.72 \pm 2.55$ \\
E & Head width & $5.30 \pm 0.68$ \\
\hline
\end{tabular}


In cattle, Silva (2003) reported that the greatest number of total defects was found in epididymal spermatozoa as compared to ejaculated spermatozoa. Assumpção, Santos, Macedo, Peixoto and Zampini (2016) reported a high percentage of spermatozoa with morphological defects in gray brocket (Mazama gouazoubira) semen collected from the epididymis, with $78 \%$ of defects occurring in the head and $74 \%$ in the tail. These results are higher than those reported in this study.

Spermatozoid defects result from changes during spermatogenesis, sperm maturation, or semen collection. These changes are caused by genetic, environmental, nutritional, pathological, iatrogenic, and age-related factors, among others (Arruda et al., 2010). There were no differences in sperm abnormality rates between the two extenders used in this study.

The morphometric data (Figure 1) of epididymal spermatozoa of Cuniculus paca shows an oval head containing three acrosomal vesicles measuring 7.54 $\pm 0.82 \mu \mathrm{m}$ in length and $5.30 \pm 0.68 \mu \mathrm{m}$ in width, a midpiece measuring $5.35 \pm 0.83 \mu \mathrm{m}$, and a tail measuring $30.72 \pm 2.55 \mu \mathrm{m}$. Total length was 43.87 $\pm 4.91 \mu \mathrm{m}$. These results differ from those obtained by Ferreira et al. (2004), who evaluated 20 sperm cells obtained through artificial vagina technique, and by Cuan-Barrera, Gómez, Parra-Sandoval, Murillo-Pacheco and Manrique (2013), who collected unspecified quantities of spermatozoa using percutaneous epididymal sperm aspiration (PESA), as presented in Table 1.

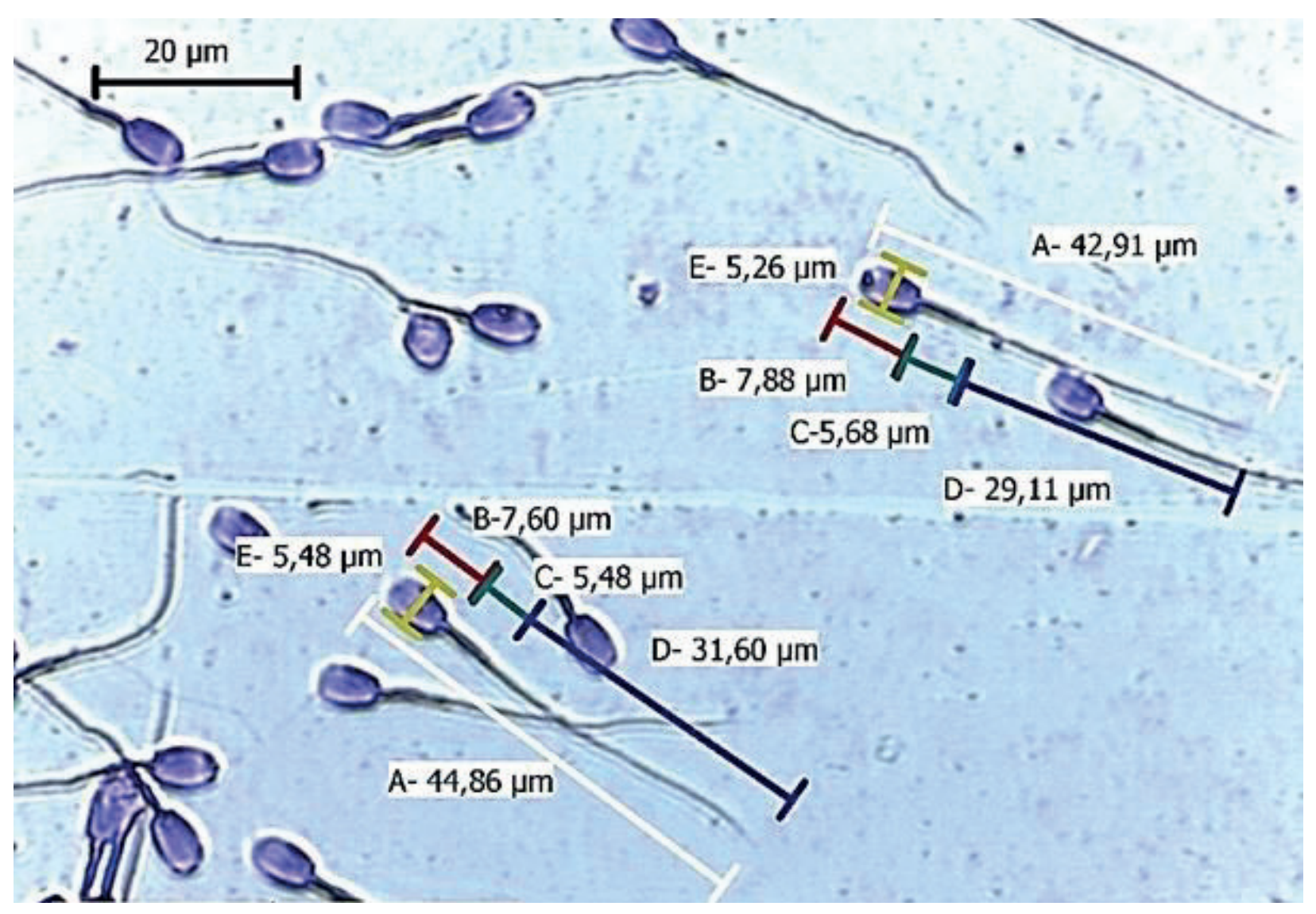

Figure 1. Measurements of C. paca spermatozoa. Light microscopy - 100x magnification - Staining: Diff-Quick. 
As for the intra-acrosomal vesicles (Figures the vas deferens and ejaculatory duct. Cuan-Barrera 2 and 3), similar characteristics were observed and reported by Hoyos et al. (2001) and Ferreira et al. (2004) in paca spermatozoa obtained by electroejaculation and artificial vagina technique, respectively, which shows that these vesicles are present even after the spermatozoa pass through

et al. (2013) and Stradiotti et al. (2015) did not report these vesicles in their studies on Cuniculus paca spermatozoa. It is important to elucidate the function of these acrosomal vesicles. Owing to their location, their function in the acrosomal reaction, an important fertilization phase, remains unknown.

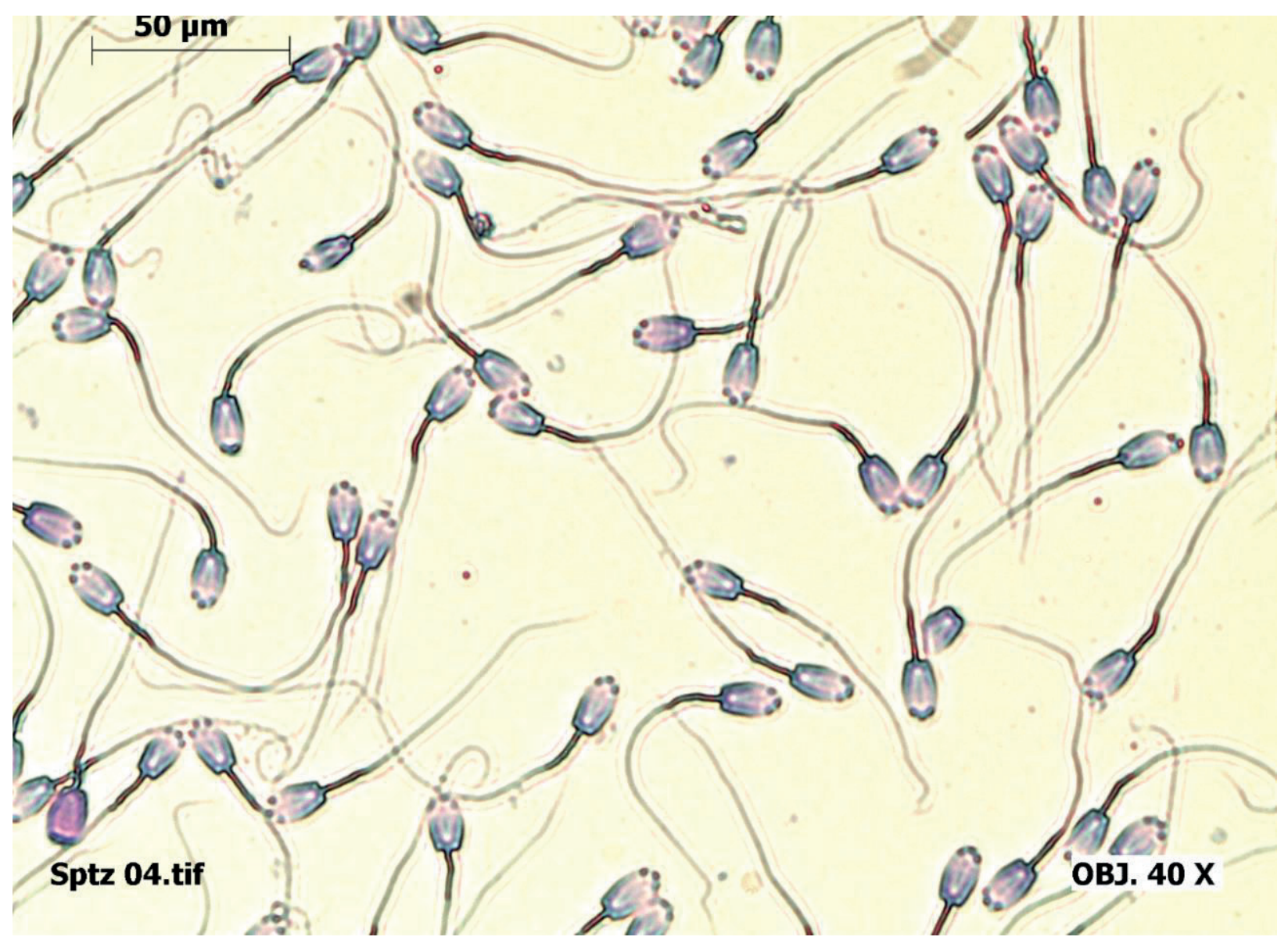

Figure 2. Cuniculus paca epididymal spermatozoa showing the three acrosomal vesicles. Phase contrast microscopy - 40x magnification - Staining: Diff-Quick. 


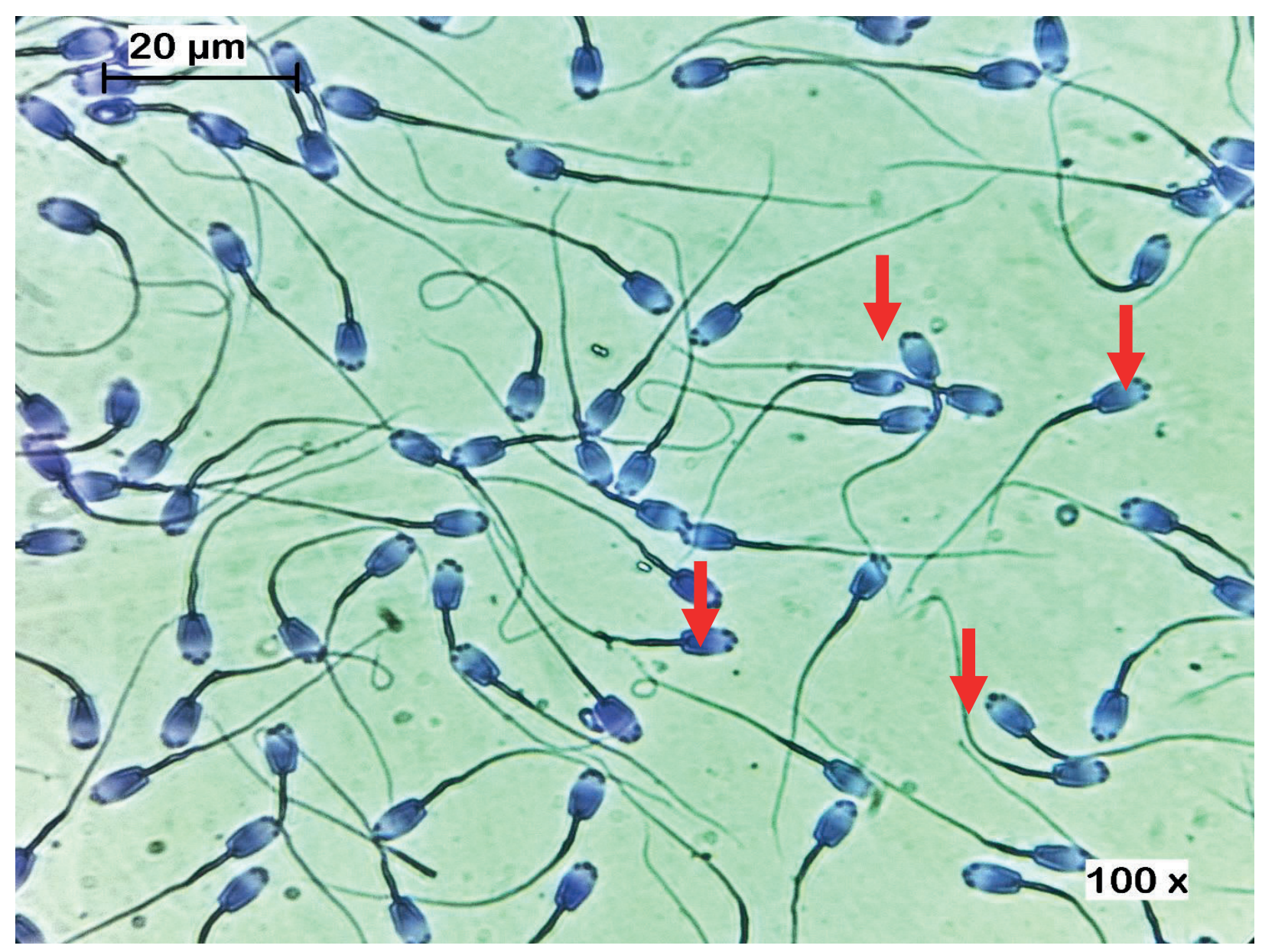

Figure 3. Cuniculus paca epididymal spermatozoa showing the three acrosomal vesicles (red arrows). Light microscopy - 100x magnification - Staining: Diff-Quick.

Both extenders used in the flotation method efficiently preserved cell membranes, an important factor for fertilization. ACP-123 ${ }^{\circledR}$ is the most recommended for maintenance of epididymal spermatozoa of paca $(\mathrm{p} \leq 0.05)$, as it preserved $83.8 \%$ of viable spermatozoa as compared to Botusemen Special ${ }^{\circledR}$, which preserved $72.9 \%$.

Nunes and Salgueiro (2012) reported that coconut water has been frequently used in animal reproduction with satisfactory results, as observed in seminal preservation studies on domestic and wild animals. Milk-based extenders are rich in lipoproteins, stabilizing protein elements of the sperm cell membrane (Oliveira, Oliveira, Celeghini, Fernandes, \& Mattos, 2013) as well as proteins such as caseins (which prevent intracellular accumulation of high amounts of calcium ions that damage cells) and serum proteins, representing $80 \%$ and $20 \%$ of total milk proteins, respectively (Castro, 2014). Coconut water was more effective than Tris in processing and cryopreserving agouti semen (Silva et al., 2011).

These results were better than those obtained by Hoyos et al. (2001), probably due to the use of different sperm collection and evaluation techniques, since they collected paca spermatozoa using electroejaculation, which requires sedation and induces stress in the animals. In addition, they used FITC-propidium iodide for membrane integrity analysis, reporting $47.5 \%$ intact membranes. 
Eosin-nigrosine and Diff-Quick were efficient stains for the assessment of membrane integrity and morphological evaluation, respectively. More than $70 \%$ of cells had no morphological abnormality and presented intact membranes, indicating their mobility in the female genital tract as well as their fertile capacity.

We emphasized that: due to (i) the scarcity of studies in this area, and (ii) the small number of animals studied, all parameters evaluated in this study should be re-tested using both epididymal spermatozoa, which are important in conservation programs and genetic banks, and spermatozoa obtained with ejaculatory techniques.

\section{Conclusion}

We concluded that epididymal spermatozoa of pacas diluted in ACP ${ }^{\circledR}$ and Botusemen Special ${ }^{\circledR}$ can be used in assisted reproduction techniques. Also, this study encourages further research on the role of the three acrosomal vesicles found in the spermatozoa of this species, a question that is yet to be answered, in order to increase the knowledge of the reproductive biology of wild species like the spotted paca.

\section{Acknowledgments}

We thank the Federal University of Acre and the Wildlife Support Laboratory.

\section{References}

Arruda, R. L., Orro I. R, Passos T. S, Costa e Silva, E. V, \& Zúccari, C. E. S. N. (2010). Técnicas para avaliação laboratorial da integridade estrutural e funcional do sêmen congelado de touros. Revista Brasileira de Reprodução Animal, 34(3), 168-184.

Arruda, R. L., Celeghini, E. C. C., Rossetto Garcia, A. R., Santos, G. D. C., Leite, T. G., Oliveira, L. Z.,... Rodrigues, M. P. (2015). Morfologia espermática de touros: interpretação e impacto na fertilidade. Revista Brasileira de Reprodução Animal., Belo Horizonte, 39(1), 47-60.
Assumpção, T. I., Santos, A. L. Q., Macedo, G. G., Peixoto, L. R., \& Zampini, A. C. A. (2016). Coleta e avaliação morfológica dos espermatozoides epididimários de veado-catingueiro Mazama gouazoubira Fischer, 1814. Investigação, 15(5), 49-54.

Assumpção, T. I. (2017). Coleta de sêmen em animais selvagens realidades e desafios. Anais da Reunião da Associação Brasileira de Andrologia Animal (ABRAA), Corumbá, Mato Grosso do Sul. Recuperado de https://ainfo.cnptia.embrapa.br/digital/bitstream/ item/164360/1/DOC-146-.pdf\#page=13.

Axnér, E.; Holst Ström, B., \& Linde-Forsberg, C. (1997). Sperm morphology is better in the second ejaculate than in the frist in domestic cats eletroejaculated twiceduring the same period of anesthesia. Theriogenology, 47, 929-934. doi: 10.1016/S0093691X(97)00048-4

Batalha, L. M., \& Oba, E. (2006). Caracterização morfométrica e morfológica de célula espermática de capivara (Hydrochoerus hydrochaeris). Archives of Veterinary Science, 11(1), 66-72.

Blom, E. (1973). The ultrastructure of some characteristic sperm defects and a proposal for a new classification of the bull spermiogram. Nordisk Veterinaermedicin, 25, 383-391.

Bonilla-Morales, M. M., Rodríguez Pulido, J., \& Murillo Pacheco, R. (2013). Biology of agouti (Cuniculus paca Brisson): a breeding perspective. CES Medicina Veterinaria y Zootecnia, 8(1), 129-142.

Castelo, T. S. (2015). Obtenção e conservação de espermatozoides de cutia (Dasyprocta leporina Linneaus, 1753) do semiárido brasileiro. Tese (Doutorado em Biotecnologia), Universidade Federal do Rio Grande do Norte, Rio Grande do Norte.

Castro, F. S. (2014). Comparação entre diferentes tipos de leites como diluentes para sêmen equino refrigerado. Dissertação de Mestrado, Universidade Federal do Rio Grande do Sul, Porto Alegre, Rio Grande do Sul.

Correia, F. C. D. S., Francisco, R. S., Souza, V. T., Ribeiro, V. M. F., \& Gomes, F. A. (2016). Criação de pacas (Cuniculus paca) como alternativa de diversificação de produção e renda em Rio Branco-Acre. Arquivos de Ciências Veterinárias e Zoologia da UNIPAR, 19(2), 81-89. doi: 10.25110/arqvet.v19i2.2016.5925

Cuan-Barrera, J., Gómez. J., Parra-Sandoval, C., Murillo-Pacheco, R., \& Manrique, J. F. (2013). Memorias de la Conferencia Interna en Medicina y Aprovechamiento de Fauna Silvestre, Exótica y no Convencional. (Vol. 9, n. 1, pp. 15-16). Colombia, Asociación de Veterinarios de Vida Silvestre. 
Emmons, L. (2016). Cuniculus paca. The IUCN Red List of Threatened Species 2016: e.T699A22197347. Recuperado de https://www.iucnredlist.org/ species/699/22197347. doi: 10.2305/IUCN. UK.2016-2.RLTS.T699A22197347.en

Fernández-Santos, M. R., Martínez-Pastor, F., GarciaMacías, V., Esteso, M. C., Soler, A. J., Paz, P.,... Garde, J. J. (2007). Sperm characteristics and DNA integrity of Iberian red deer (Cervus elaphus hispanicus) epididymal spermatozoa frozen in the presence of enzymatic and nonenzymatic antioxidants. Journal of Andrology, 28(2), 294-305. doi: 10.2164/jandrol.106.000935

Ferreira, A. C. S., Guimarães, D. A., Luz-Ramos, R. S., Bastos, L. V., \& Ohashi, O. M. (2004). Morphologial and biometrics characteristics of agouti paca semen, raised in captivity. In: XV International Con-gress on Animal Reproduction. Reprodução Animal, (Vol. 9, p. 224-224). Porto Seguro, Brasil.

Freneau, G. E. (2011). Aspectos da morfologia espermática em touros. Revista Brasileira de Reprodução Animal, 35(2), 160-170.

Hoyos, D., López, J., Ramírez, A., Valencia, F., Molina, S., Sanchéz, J.,... Oliveira-Angel, M. (2001). Caracterización espermática de agouti paca y agouti taczanowskii. Revista Colombiana de Ciencias Pecuarias, 14, 86.

Martins, C. F., Dode, M. N., \& Silva, A. E. D. F. (2016). Atlas de morfologia espermática bovina.

Matos, D. L., Araújo, A. A., Roberto, I. G., \& Toniolli, R. D. L. (2008). Análise computarizada de espermatozóides: revisão de literatura. Revista Brasileira de Reprodução Animal, 32(4), 225-232.

Nunes, J. F., \& Salgueiro, C. C. M. (2011). Strategies to improve the reproductive efficiency of goats in Brazil. Small Ruminant Research, 98(1-3), 176-184. doi: 10.1016/j.smallrumres.2011.03.036

Oliveira, G. C. D., Oliveira, B. M. M., Celeghini, E. C. C., Fernandes, C. B., \& Mattos, C. B. (2013). Criopreservação do sêmen equino: uma revisão. Revista Brasileira Reprodução Animal, 37(1), 23-28.
Ribeiro, V. M. F., Carvalho, Y. K. de, Peruquetti, R. C., Medeiros, L., \& Freitas, H. J. de (2017). Consumo e comercialização de carnes silvestres: potencial econômico para a Amazônia Ocidental. Journal of Amazon Health Science, 2(1), 1-8.

Ribeiro, V. M. F., Satrapa, R., Diniz, J. V. A., Fêo, H. B., Flórez, L. M. M., Satrapa, R. A.,... Oba, E. (2017). Synchronization of estrus in paca (Cuniculus paca L.): possible impacts on reproductive and productive parameters. Brazilian Journal of Veterinary Research and Animal Science, 54(1), 27-35. doi: 10.11606/ issn.1678-4456.bjvras.2017.107807

Sánchez, M. V. (2014). Morfometría geométrica aplicada al estudio evolutivo de los espermatozoides y su relación con determinantes de la fertilidad en roedores. Doctoral dissertation, Universidad Autónoma de Madrid.

Silva, A. E. D. F. (2003). Conteúdo de peptídeos e avaliação morfofisiológica dos espermatozoides do epidídimo e ejaculado de bovinos. Revista Brasileira de Zootecnia, 32(6),1890-1900.

Silva, M. A., Peixoto, G. C. X., Santos, E. A. A., Castelo, T. S., Oliveira, M. F., \& Silva, A. R. (2011). Recovery and cryopreservation of epididymal sperm from agouti (Dasiprocta aguti) using powdered coconut water (ACP-109c) and Tris extenders. Theriogenology, 76(6), 1084-1089. doi: 10.1016/j. theriogenology.2011.05.014

Stradiotti, C. G. P., Silva, J. F. S., Cunha, I. C. N., Stradiotti, D. Jr., Cóser A. C., Rangel, C. C.,... Almeida F. M. (2015). Desenvolvimento de metodologia para coleta de sêmen de pacas. Brazilian Journal of Veterinary Medicine, 37(3), 222-226. doi: 10.1590/S151635982003000800013

Yu,I.,\&Leibo, S.P.(2002). Recovery ofmotile, membraneintact spermatozoa from canine epididymides stored for 8 days at 4 C. Theriogenology, 57(3), 1179-1190. doi: 10.1016/S0093-691X(01)00711-7 
